\title{
Telerehabilitáció az onkológiában
}

\author{
Telerehabilitation in oncology \\ Juhász Ágnes, Hajdú Anett, Prof. Dr. Dank Magdolna \\ Semmelweis Egyetem, Belgyógyászati és Onkológiai Klinika, Budapest
}

A COVID-19 járvány miatt 2021. szeptember 19-ig Magyarországon 817159 fertőzött esetet regisztráltak, ebböl 779777 beteg már meggyógyult és 30123 halálozás történt. A pandémia miatt bevezetett korlátozások negatív hatást gyakoroltak az egészségügyi ellátórendszerre, veszélyeztetve ezzel a daganatos betegek rehabilitációs ellátását. Ennek eredményeként a telerehabilitációs ellátás elengedhetetlenné vált annak érdekében, hogy a betegeknél csökkenteni lehessen a személyes megjelenések számát. Ez az új perspektíva vezetett minket oda, hogy felülvizsgáljuk, hogy vajon a telerehabilitáció kedvezőtlen hatással van-e az onkológiai betegek rehabilitációs ellátására, vagy egy olyan lehetőség, amely szerves részévé válhat a rehabilitációs ellátásnak.

Until the 19th of September 2021 817,159 infection cases has been registered in Hungary (due to the COVID19 pandemic), of which 779,777 patients have been cured and unfortunately 30,123 deaths have occurred. Restrictions imposed due to the pandemic have had a negative impact on the health care system, endangering the care for cancer patients. As a result, telerehabilitation care has become essential in order to provide patients with a care method to reduce the frequencies of in person treatments. This new perspective has led us to review whether rehabilitation is not harmful (or is beneficial) for rehabilitation care of oncology patients, or it is any option that can become an integral part of oncology rehabilitation care.

\section{BEVEZETÉS}

A COVID-19 járvány különféle tünetekkel jelentkezhet. A legtöbb fertőzöttnél enyhe vagy közepesen súlyos lefolyású betegség alakul ki, melyből a gyógyulás klinikai gondozás nélkül bekövetkezik. Az immunszuppresszált vagy társbetegségben szenvedő betegeknél, mint például a daganatos betegeknél nagyobb a kockázata a súlyosabb szövődmények kialakulásának, nagyobb arányban van szükség kórházi kezelésre - légzési elégtelenség miatt - nehezebben küzd meg a beteg a kialakult szövődményekkel, így a mortalitás is magasabb [1]. Ezen okból kifolyólag megpróbáltunk a rehabilitációban mielőbb változásokat végrehajtani annak érdekében, hogy lecsökkentsük betegeinkkel a személyes találkozások számát, megvédve őket a fertőzés kockázatától. Kiemelt figyelmet igényelt, hogy ezen változások ne befolyásolják negatívan a rehabilitáció hatékonyságát. A nemzetközi szinten kidol- gozott útmutatásokat figyelembe véve folytattuk betegeink rehabilitációs ellátását, szem előtt tartva az irányelveinket.

\section{TELEREHABILITÁCIÓ}

Ebben a nehéz időszakban, amikor a bizonytalanság érzése magas, a multidiszciplináris csoporthoz való hozzáférés igen nagy segítséget nyújt a betegek és a családjuk érzelmi jólétéhez [2]. Amikor a telerehabilitációról beszélünk, csakúgy, mint minden más technológiával kapcsolatban, az elsődleges probléma mindig a hozzáférhetőség. Habár a kapcsolatfelvétel nem nehéz, a távoli területeken a stabil internetszolgáltatás gyakran problémás. Az aggodalom fokozódik azoknál, akiknél viszont korlátozott az internet hozzáférés és a technikai feltételek sem megfelelőek. További akadály lehet a pontos fizikai vizsgálat elvégzése, tudva, hogy a rutin klinikai gyakorlat gyakran korán felfedi a kialakult problémákat. A legnagyobb nehézség a betegek kiválasztása lehet, hogy ki az, akit a klinikán, és ki az, akit az otthonában lehet nyomon követni. Az ESMO (European Society for Medical Oncology) iránymutatásokat adott ki a betegek ellátására [3]. Például az emlő daganatos betegeknél egyértelmúen ajánlott volt a telemedicinára való áttérés. Ezen betegeknél a megfelelő osztályozás minden esetben az orvos tapasztalataira épül [4].

\section{ONKOLÓGIAI REHABILITÁCIÓ}

Az onkológiai rehabilitáció magába foglalja az egészséget optimalizáló beavatkozásokat, amelyek célja a betegek azon képességének a javítása, amivel a lehető legjobban tolerálják a daganatellenes kezeléseket. A preoperatív rehabilitáció multimodális és bebizonyosodott, hogy csökkenti a postoperatív szövődményeket, gyorsítja a felépülést, lecsökkentve ezzel a kórházi kezelések számát [5]. A postoperatív rehabilitáció a fizikai aktivitás tükrében nagyon sokféle lehet, de általában mindig a beavatkozástól, illetve az érintett régiótól függ a kezelés menete. A gyógytorna célja ilyenkor a mozgástartomány és a felborult izomegyensúly teljes helyreállítása, valamint egyénre szabott táplálás terápia mellett betegeink életminőségének a javítása.

\section{REHABILITÁCIÓS LEHETŐSÉGEK A PANDÉMIA ALATT}

\section{Gyógytorna}

A COVID-19 járvány alatt a telerehabilitáció bevezetésével a fizioterápiás lehetőségek (gyógytorna, nyirokmasszázs, elektroterápia) közül a gyógytornát és a nyirokkezelést tudtuk 
folytatni betegeinknél, valamint a táplálásterápiát és a pszichoterápiát. A járvány egyik nem kívánatos hatása, hogy megnő a betegeknél az otthon töltött passzív idő, ezáltal lecsökken a kardio-pulmonális kapacitás, az izomtömeg és az izomerő, ami fokozott morbiditáshoz és mortalitáshoz vezet, elörehaladott rosszindulatú betegek esetében [6]. A gyógytorna szerves része az integratív onkológiának. Lényegesen mérsékeli a fáradságot, a pszicho-szociális diszfunkciókat, miközben fokozza az aerob fitneszt, optimalizálja a testösszetételt, valamint az életminőséget.

A daganatos betegek mozgásterápiájának a rezisztencián (ellenálláson) alapuló edzés a fő alkotóeleme, mely növeli a kontraktilis fehérje tömegét, redukálja a rehabilitációban résztvevők esetében a szarkopéniát és a testzsírt, valamint növeli az izomerőt és ezáltal kedvező hatással van az életminőségre. Az aerob fitnesz fokozza a mitokondriumok számát és az oxidatív enzimek aktivitását a vázizomban, valamint hatékonyabb mitokondriális szabályozást alakít ki a szervezetben.

A neoadjuváns kezelésben (különböző szervek daganatai esetén) részesülő betegröl, ha az orvos úgy gondolja, hogy megfelelő az online rehabilitációs programban való részvételhez és minden lehetőség adott a beteg számára (internet, számítógép), akkor kap egy értékelést, melyet Naomi és munkatársai az 1 . táblázatban a klinikai vizsgálatuk előzetes adatai alapján állították össze, mely különböző szintekből áll (alapszint, középszint és haladó), amely tájékoztatást ad a beteg aktuális fizikai állapotáról és útmutatást ad az otthoni fizikai aktivitáshoz [7]. A bizonyítékok arra utalnak, ha a betegek nem részesülhetnek személyes rehabilitációban, nagyon jól működik a telerehabilitáció és egyszerủen kivitelezhető a $30 \mathrm{mp}$-es teszt. A részvevőket a különböző szinteken arra ösztönzik, hogy heti háromszor teljesítsék a gyakorlatokat mindaddig, amíg a távolságtartási korlátozások érvényben vannak. Ez a fajta megközelítés az inaktív időszakban és a neoadjuváns kezelés során jelentősen csökkenti az izom fájdalmakat és a betegek erőnléte is szinten tartható a hosszantartó daganatellenes terápia alatt [7]. A posztoperatív időszakban jelenlévő telerehabilitációval kapcsolatos kutatások még korlátozottak, de mint mindenhol, itt is arra helyeződik a hangsúly, hogy a műtét utáni szövődményeket jelentős mértékben csökkenteni lehessen. Ezenfelül fontos a lymphoedema megelőzése, a mozgástartomány fokozása, illetve a fáradság csökkentése, továbbiakban pedig az izomerő és az izomtömeg növelése a cél [8]. A vállízület korai mobilizációja nagy szerepet játszik a váll kinematikájának megőrzésében és a letapadások megelőzésében. Az ún. inga gyakorlatok csökkentik a fájdalmat a figyelemelterelés és az oszcilláció hatásán keresztül. Az irányított gyakorlatok, mint például a flexio, abdukció és a rotatio hatékonyabb a mozgásterjedelem fokozásában, mint az egyéb szabad váll gyakorlatok. A nyújtást legalább 30 mpig ajánlott kitartani [8]. Klinikánkon, az online találkozás során 5 perc bemelegítéssel kezdtünk, majd ezt követően 25 perc rezisztencia edzés következett, amit 10 perces strechinggel és légzőtornával zártunk.

\section{LYMPHOEDEMA}

A kialakult nyiroködéma esetén a manuális nyirokkezelés oktatása szükséges és az online nyomon követés elengedhetetlen, a fizikai vizsgálatot módosítani kell, hogy megfeleljen az online módszerhez. A beteg oktatást kap arról, hogyan mérje meg a felső végtag kerületét, a szükséges anatómiai pontokat használva egy mérőszalag segítségével. Az aktív mozgásterjedelmet vizuálisan szükséges értékelni. Egyéb más technika során a betegnek szüksége van a verbális és a demonstratív útmutatásra. Ilyen például a megfelelő fáslizás, valamint a fásliban végzett torna [8].

\section{TÁPLÁLÁSTERÁPIA}

A COVID-19 járvány változásokat hozott a táplálásterápiában is a járványügyi intézkedések következtében, különösen a tápláltsági állapot felmérésében. Klinikánkon a tápláltsági állapot rizikószűrése az Nutrition Risk Screening 2002 kérdőív (NRS-2002) segítségével történik, míg a konkrét tápláltságiállapot-felmérés bioimpedancia módszerrel, InBody 770 testösszetétel-mérő géppel. A segítségével nyrhető adatok közül az alábbiakat vesszük figyelembe a tápláltsági állapot felmérés során: testtömeg, teljes testvíz, fehérje, izomtömeg, teljes testzsír, viszcerális zsír, zsírmentes testtömeg, zsírmentes testtömeg index.

Mivel Klinikánkon a pandémia alatt a személyes konzultációra csak indokolt esetben volt lehetőség, a távoli antropometriai vizsgálómódszerek jelentették a megoldást a tápláltsági állapot felmérésében. A dietetikai oktatáson való személyes megjelenés abban az esetben volt lehetséges, amikor a beteg a klinikán megjelent daganatellenes kezelése céljából.

A telefonos konzultáció első lépése egy táplálkozási anamnézis felvétele volt. Irányított kérdésekkel fel lehet térképezni a beteg táplálkozási attitúdjeit, problémáit és az alultápláltsággal összefüggő rizikófaktorokat. Az anamnézis legföbb kérdései között szerepelt, hogy az utóbbi 3 hónapban történt-e változás testtömeg, az étvágy, és a táplálékfelvétel minősége és mennyisége tekintetében, illetve, hogy melyek a diétát, táplálást befolyásoló fontosabb gyógyszerek. Fennáll-e dietetikai szempontból lényeges betegség, étkezéssel, emésztéssel összefüggő panasz vagy táplálkozás nehezítettségére utaló állapot.

A telefonos konzultációk során testösszetétel-mérés nélkül dolgoztuk ki a táplálási tervet. Csupán a testtömeg mérésével nem állapítható meg a tápláltsági állapot. Az InBody mérést helyettesítették az antropometriai mérőmódszerek, hiszen alacsony költségü, egyszerüen kivitelezhető, minimálisan invazív, és minden korcsoportban és életkorban alkalmazható [9], ugyanakkor jellege csupán tájékoztató.

A testtömeg mérése kalibrált mérleggel tanácsos, reggel széklet- és vizeletürítés után, fehérnemüben. A mérés esetén hibaforrás lehet a különböző napszakokban való mérés, valamint az esetlegesen fennálló ödéma.

A legtöbb kemoterápiás kezelés dózisának kiszámítása testfelszín alapján történik, ezért a pontos testmagasságnak 
ismertnek kell lennie. Ez az információ a beteg egészségügyi dokumentációjában megtalálható. További antropometriai adatként a derék- és csípőkörfogat adatait használtuk. A derékkörfogat mérése a spina iliaca anterior superior és a legalsó borda közötti távolság felénél történik, nyugodt kilégzés utáni állapotban, éhgyomorra és vízszintes síkban. Ez az érték az ascites fennállásának és módosulásának is jelzője lehet. Obes felnőttek esetében nehézséget okozhat a derékkörfogat mérésének pontos megállapítása. A csípőkerület a medence régiójának legnagyobb körfogata a tomporon. A mérés elvégzésekor a merőszalag mindkét trochanter major-t érintse, és vízszintes síkban haladjon. Ezzel a maximális csípőkörfogatot kapjuk [10]. Azonban azt, hogy a méréseket helyesen hajtották-e végre, nem tudtuk teljes mértékben ellenőrizni, de páciensek pontos utasításokat kaptak arra vonatkozóan, hogyan végezzék el a testméréseket a lehető legpontosabb módon.

Ezen adatok során 10\% hibaszázalékon belül lehet számolni, hiszen az otthon használt mérőeszközöknek a minősége nem minden esetben kielégítő. Továbbá lényeges megkérdezni, hogy más személy segíthet-e a mérésekben, valamint a betegnek is motiváltnak kell lennie, hogy az antropometriai vizsgálatot a lehető legmegbízhatóbb módon végezze. Segítséget jelent, ha a mérési folyamatot videón követni tudjuk, hiszen élő szóval lehet utasítani a beteget, hogyan helyezze el a mérőszalagot.

Meghatározásra került a beteg energia, fehérje, zsír és szénhidrát szükséglete. Ebben irányadó az Európai Klinikai Táplálási és Metabolizmus Társaság szakmai protokollja. A tápláltsági állapot felmérésében segítséget nyújt még a beteg dokumentációjában található biokémiai markerek (pl. szérumfehérjék vizsgálata) is.

A páciensek 3 napos táplálkozási naplót készítettek, amelyben két nem egymást követő hétköznap és egy hétvégi nap étkezéseit pontos ételmennyiséggel rögzítették. A napló kiértékelésével jó közelítéssel megbecsülhető az energia-és tápanyagbevitelük. Ha bármilyen emésztőrendszeri panaszt észleltek, ezt a feljegyzést kiegészítették tüneti naplóval is, hiszen ez segíthet a panaszt okozó nyersanyagok felderítésében. A táplálkozási napló módszerének buktatója, ha a beteg nem a ténylegesen elfogyasztott ételek adatait rögzíti. Fontos meggyőzni, hogy ne a kezelő személyzetnek tetsző adatokat akarjon adni, hanem a valós adatokról számoljon be.

Ezenkívül mindig javasoljuk online kalóriaszámláló alkalmazás használatát a pontos tápanyagbevitel követése céljából. Ennek kiértékelésében is megfelelő segítséget kaptak, az esetlegesen fennálló diétahibák javítására sor került. A naplók kiértékelése alapján azt tapasztaltuk, hogy a járvány az étkezési szokásokat nagymértékben befolyásolta, kiemelve a magas feldolgozottságú élelmiszerek jelenlétét a hosszú eltarthatóságuk és a járvány kezdetén való élelmiszerfelhalmozás miatt. A friss gyümölcsök és zöldségek rendszeres fogyasztása is csökkent a korlátozott tárolási idő és a pandémia okozta áremelkedés miatt. Az egészséges élelmiszerekhez való korlátozottabb hozzáférés is hozzájárulhat a betegek tápláltsági állapotának romlásához [7]. Megnőtt az interneten vásárolható élelmiszerek és ezek mellett az étrendkiegészítők aránya. Ezen szerek esetében elengedhetetlen volt a klinikai szakgyógyszerészünkkel való személyre szabott konzultáció, hiszen a daganatellenes kezelések és más hatóanyagok közötti interakcióra minden esetben gondolni kell.

A telefonos konzultáció során a betegek egyénre szabott diétás tanácsadásban részesültek, megbeszélésre kerültek a diéta fő szempontjai, a nyersanyagválogatás, valamint a konyhatechnológiai eljárások is. Az étrendről minden esetben online tájékoztató anyagot kaptak. Amennyiben a tápláltsági állapotuk indokolttá tette, tápszeres szupplementáció is meghatározásra került. A tápszerek kiválasztása a beteg egyéni igényeinek és társbetegségeinek figyelembevételével

\begin{tabular}{|c|c|}
\hline \multicolumn{2}{|l|}{30 mp-es teszt } \\
\hline Technika: & Eredmények: \\
\hline $\begin{array}{l}\text { Helyezzen egy stobil széket a falhoz, amelyet a teszt } \\
\text { sorón használ. A beteg a szék közepén, egyenes }\end{array}$ & \# Helyes felällósok szómo 30 mp alatt \\
\hline $\begin{array}{l}\text { háttal, a padlón elhelyezett labbokkal ül. A betega } \\
\text { karjoit keresztbe teszi és a mellikashoz tartjo. }\end{array}$ & Szint $1: \leq 11$ felalllós \\
\hline Felál, majd visszatér oz eredeti ülö helyzetbe. & Szint 2: $12-24$ felállás \\
\hline $\begin{array}{l}\text { A betegnek a lehetổ legtöbbszōor kell felällini } 30 \mathrm{mp} \\
\text { alatt. A betegnek teljesen le kell ülni a felällások } \\
\text { utón. A helytelenül kivitelezett felällósokot nem } \\
\text { számoljuk. }\end{array}$ & Szint 3: 225 felállás \\
\hline \multicolumn{2}{|l|}{ Gyakorlatok } \\
\hline \multicolumn{2}{|c|}{ Szint 1: kezdö } \\
\hline 10 perc bemelegités & Ellenállásos gyakorlatok: \\
\hline 20 perc kardiovaszkuláris séta & hasprés \\
\hline 30 perc ellenállás & \\
\hline $2 \cdot 3$ széria 12 ismétléssel & oldalsó lábemelés \\
\hline Súly nélkül, csak a test ellenállása & $\begin{array}{l}\text { állva sarok felhúzás } \\
\text { fali fekvótámasz }\end{array}$ \\
\hline \multicolumn{2}{|c|}{ Szint 2: középszint } \\
\hline 10 perc bemelegités & Ellenállásos gyakorlatok: \\
\hline 20 perc cardiovaszkuláris: & hid \\
\hline gyors séta & mellkasi gyakorlatok \\
\hline elliptikus tréner vagy szoba kerékpár & triceps extensio \\
\hline 30 perc ellenállás & módositott plank \\
\hline 3 széria 12 ismétléssel & evezés \\
\hline $5 \mathrm{~kg}$ sưly vagy ennek megfelelő & guggolás \\
\hline \multicolumn{2}{|c|}{ Szint 3: haladó } \\
\hline 10 perc bemelegités & Ellenállásos gyakorlatok: \\
\hline 20 perc kardiovaszkuláris & triceps extensio \\
\hline joggingolás & plank \\
\hline elliptikus tréner vagy szobakerékpár & fekvótámaszok \\
\hline 30 perc ellenállás & forditott kitōrés \\
\hline 3 széria a 12 ismétléssel & evezés \\
\hline $5-10 \mathrm{~kg}$ súly vagy ennek megfelelỗ & $\begin{array}{l}\text { egylabu hid } \\
\text { guggolás }\end{array}$ \\
\hline \multicolumn{2}{|l|}{ Táplálékkiegészítök } \\
\hline \multicolumn{2}{|c|}{$\begin{array}{l}\text { Számos fehérjekiegészitó termék van forgalomban, amelyek a magas cukortartalom miatt hátrányosan } \\
\text { befolyásolhatják a glikémiás kontrollt. Javasolt fehérjeporok hozzáadása az ételekhez, melyeket a bete } \\
\text { fogyaszt. }\end{array}$} \\
\hline \multicolumn{2}{|l|}{ Dohányzásról való leszokás } \\
\hline Stressz csōkkentő stratégiák & \\
\hline
\end{tabular}

1. táblázat

Példa multimodális rehabilitációs programra neoadjuváns terápián áteső onkológiai betegek számára [7] 
történt. Különös figyelmet fordítottunk arra, hogy a szarkopéniát időben diagnosztizáljuk és megfelelő legyen a fehérjebevitel.

A telemedicina praktikus módja annak, hogy segítsen fenntartani a dietetikus-beteg kapcsolatot, miközben mérsékeli a COVID fertőzés kockázatát. A betegek pontosabban tartották a konzultációs időpontokat, mivel az ellátás otthonról is elérhető volt [11]. Azonban ezek mellett problémát jelentett a tápláltsági állapot nem pontos felmérése, hiszen ezen betegcsoport fokozott rizikóval rendelkezik a kóros tápláltági állapotok kialakulása szempontjából.

\section{ÖSSZEFOGLALÁS, KÖVETKEZTETÉSEK}

Tanulmányok kimutatták, hogy az online konzultációk nem veszélyeztetik a rehabilitációban résztvevők ellátását. Ezek az intézkedések felhasználhatók adott időszakban a betegek funkcionális állapotának megítélésére, az általános fizikai felmérésre, ami lehetőséget ad arra, hogy szükséges korrekciók történjenek akár a teljesítménystátusz, akár a tápláltsági álla- pot tekintetében. Számos tanulmány azt sugallja, hogy a teleonkológia költséghatékony, ami nagyon magas betegelégedettséggel társul [12-13]. A telerehabilitációnak még vannak nem kellően kidolgozott komponensei, amelyeken javítani kell, ennek ellenére a telerehabilitáció igen ígéretes lehetőség a betegek ellátásában, nemcsak a világjárvány idejére, hanem a későbbiekben normális ellátás részévé is válhat. Ezeket az ajánlásokat kell felhasználni útmutatásként az onkológiai ellátás különféle szempontjainak rangsorolásához annak érdekében, hogy enyhítsék a COVID-19 járvány daganatos betegek kezelésére gyakorolt negatív hatásait. A helyzet változásban van, és folyamatosan monitorozott gyakorlati lépésekre van szükség a betegek kezelésével járó kihívások alkalmazásához, miközben biztosítják jogaikat, biztonságukat és jólétüket. A szakembereknek egyensúlyba kell hozni a testi-lelki igényeket és az online konzultációk rendszeressé tételét. Nyilván mindig lesz olyan helyzet, amikor a fizikai jelenlét mindenképpen szükségessé válik, de fontosnak tartottuk, hogy az általunk már a napi gyakorlatba illesztett módszert szélesebb körben is ismertté tegyük.

\section{IRODALOMJEGYZÉK}

[1] Shirke MM, Shaikh SA, Harky A: Implications of Telemedicine in Oncology during the COVID-19 Pandemic, Acta Biomed 2020; Vol. 91, N. 3: e2020022

[2] Grewal US, Terauchi S, Shaalan Beg M: Telehealth and Palliative Care for Patients with Cancer: Implications of the COVID-19 Pandemic, JMIR Cancer 2020;6(2): e20288 https://doi.org/10.2196/20288

[3] ESMO. Cancer patient management during the COVID19 pandemic (2020). www.esmo.org/guidelines/cancerpatient-management-during-the-covid-19-pandemic [Megtekintés dátuma: 2021.08.15)

[4] Elkaddoum R, Haddad FGh, Eid R, \& Kourie HR: Telemedicine for cancer patients during COVID-19 pandemic: between threats and opportunities, Future Oncol. (2020) 16(18) 1225-1227

https://doi.org/10.2217/fon-2020-0324

[5] Carli F, Silver JK, Feldman LS et al.: Surgical prehabilitation in patients with cancer: state-of-the-science and recommendations for future research from a panel of subject matter experts. Phys Med Rehabil Clin N Am. 2017; 28: 49-64.

https://doi.org/10.1016/j.pmr.2016.09.002

[6] Silver JK: Prehabilitation Could Save Lives In a Pandemic, The BMJ. Availableat: https://blogs.bmj.com/ bmj/2020/03/19/julie-k-silver-prehabilita_tion-couldsave-lives-in-a-pandemic/2020 Mar 19. [Accessed March 22, 2020] https://doi.org/10.1136/bmj.m1386

[7] Sell NM, Silver JK, Rando S et al: Prehabilitation Telemedicine in Neoadjuvant Surgical Oncology Patients During the Novel COVID-19 Coronavirus Pandemic,
Annals of Surgery, Volume 272, Number 2, e81-83, August 2020 https://doi.org/10.1097/SLA.0000000000004002

[8] de Rezende LF, Francisco VE, Franco RL: Telerehabilitation for patients with breast cancer through the COVID-19 pandemic, Breast Cancer Research and Treatment 2021,185:257-259 https://doi.org/10.1007/s10549-020-05926-6

[9] Bagni UV, da Silva Ribeiro DK., Bezerra DS, et al.: Anthropometric assessment in ambulatory nutrition amid the COVID-19 pandemic: Possibilities for the remote and in-person care. Clinical Nutrition ESPEN, 41 (2021) 186-192 https://doi.org/10.1016/j.clnesp.2020.11.022

[10] Figler M (szerk.): Klinikai és gyakorlati dietetika, Medicina Könyvkiadó Zrt, (2015) 55-62

[11] Brunton C, Arensberg MB, Drawert S et al: Perspectives of Registered Dietitian Nutritionists on Adoption of Telehealth for Nutrition Care during the COVID-19 Pandemic. Healthcare, (2021) 9 (2), 235. https://doi.org/10.3390/healthcare9020235

[12] Hiratsuka V, Delafield R, Starks H et al: Patient and provider perspectives on using telemedicine for chronic disease management among Native Hawaiian and Alaska Native people. Int J Circumpolar Health, (2013) 72 https://doi.org/10.3402/ijch.v72i0.21401

[13] Turvey C, Fortney J: The Use of Telemedicine and Mobile Technology to Promote Population Health and Population Management for Psychiatric Disorders, Curr Psychiatry Rep (2017) Oct 16;19(11):88. https://doi.org/10.1007/s11920-017-0844-0 


\section{A SZERZŐK BEMUTATÁSA}

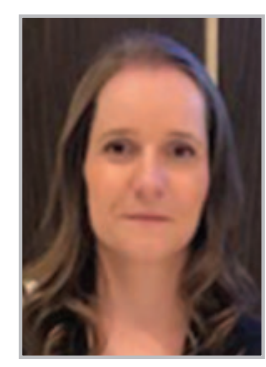

Juhász Ágnes a Pécsi Tudományegyetem Egészségtudományi Kar zalaegerszegi képzési központjában végzett 2009-ben gyógytornász szakon. 2010-ben szerzett lymphoterapeuta,

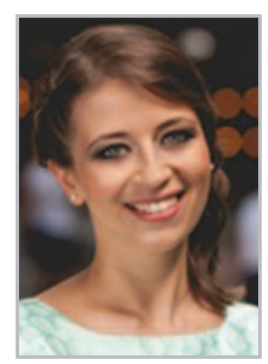

Hajdú Anett a Semmelweis Egyetem Egészségtudományi Karán végzett 2014-ben dietetikusként, 2020-ban okleveles táplálkozástudományi szakemberként szerzett diplomát. Pályáját az Országos Onkológiai Intézetben kezdte, majd 2017 óta dolgozik a Semmel-

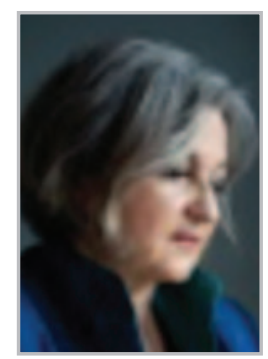

Prof. Dr. Dank Magdolna a Semmelweis Egyetem ÁOK Belgyógyászati és Onkológiai klinikájának igazgatóhelyettese az Onkológiai Profil vezetője. Nevéhez füződik az onkológiai betegek rehabilitációjának megszervezése, és majd 2019-ben manuálterapeuta képesítést. 2009-től a budapesti Károlyi Sándor Kórház sebészetén dolgozott, majd 2016-tól a Semmelweis Egyetem Belgyógyászati és Onkológiai Klinika Onkológiai Profiljának a munkatársa.

weis Egyetem Belgyógyászati és Onkológiai Klinika Onkológiai Profiljának klinikai dietetikusaként. Fontosnak tartja, hogy a klinikán a betegek egyénre szabott táplálásterápiában részesüljenek, segíti a betegeket a daganatellenes kezelések alatt a helyes diéta elsajátításában, az esetlegesen fennálló társbetegségeik figyelembevételével.

annak felvállalása, hogy az áttétes daganatos betegeknek is szükséges van mozgásszervi rehabilitációra. Fontosnak tartotta, a pandémia megváltozott helyzetéhez való alkalmazkodást, a telerehabilitáció bevezetését. Az általa vezetett egység dietetikusok és gyógytornászok számára gyakorlati képzőhely is.

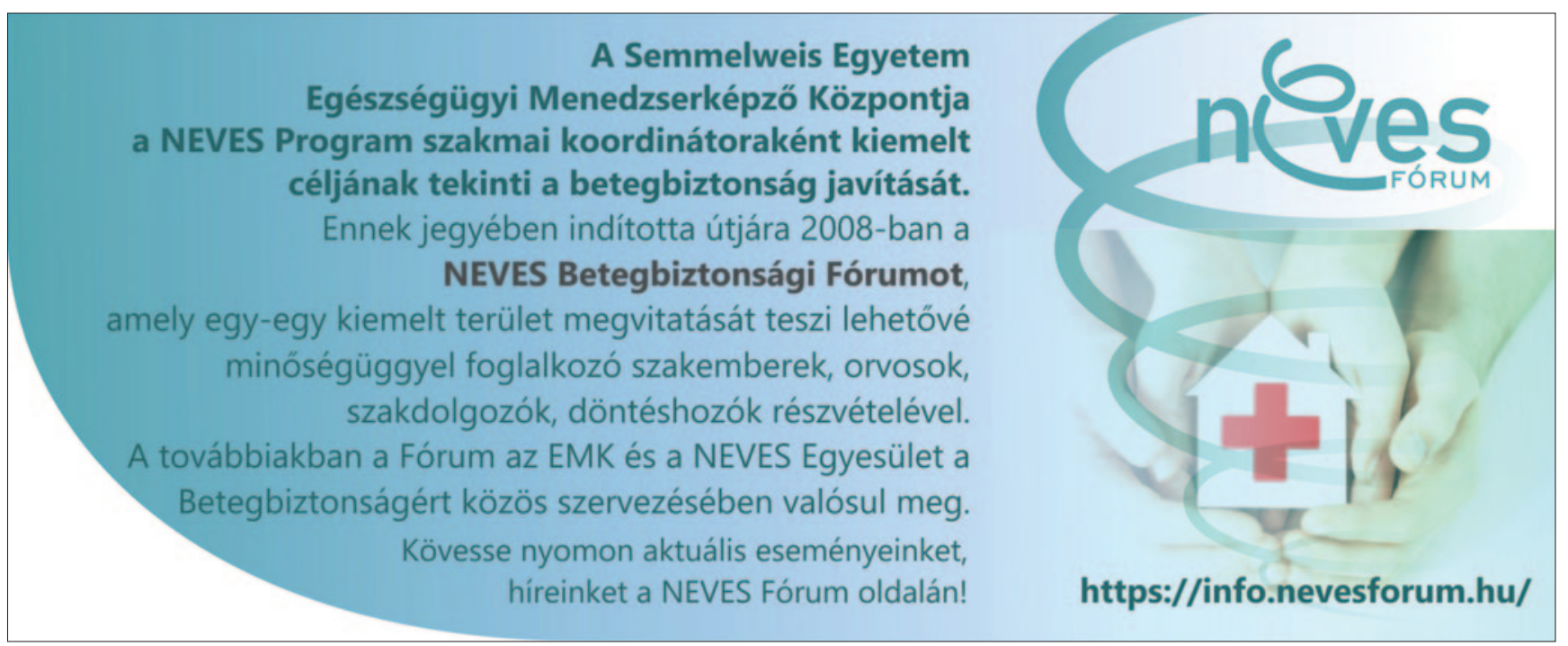

